\title{
'The Little Purple Book', 2nd Edition: Cell Therapy and Regenerative Medicine Glossary
}

"The medical specialty of regenerative medicine and the platform technology of living cells as therapies have many of their own unique challenges; however, the need for harmonization across national and international boundaries is an issue that faces them both."

\section{KEYWORDS: cell therapy $\approx$ glossary $\approx$ harmonization $\approx$ regenerative medicine - regulation $\approx$ standards}

Regenerative medicine and cell therapy are rapidly becoming global multibillion dollar healthcare sectors [1]. Both are unique and disruptive to established treatment regimens, medical practices and healthcare business models [1-3]. The medical specialty of regenerative medicine and the platform technology of living cells as therapies have many of their own unique challenges; however, the need for harmonization across national and international boundaries is an issue that faces them both. Thus, all the respective parties from both sectors need to be able to properly communicate their ideas, opinions and solutions, and interact with ease. This is especially demanding given the large numbers of diverse direct stakeholder groups involved in both sectors, including patients, the general public, politicians, scientists, engineers, clinicians, industrial workers, regulators and funders, not to mention all the indirect enablers (i.e., patent lawyers, tools and reagent manufacturers, and storage and distribution companies - to name but a few). There is, therefore, a very real and urgent need for an up-todate, high-quality, consensus-driven glossary of essential specialist terms.

"...Future Medicine is very proud to publish the second edition of what has become a highly popular and much used glossary as a supplement to this current issue."

The first glossary in the regenerative medicine field was masterminded by the British Standards Institution (BSI) in 2008 under the very capable management of Alex Kay (Project Manager, BSI). To greatly increase awareness along with its availability and hence its impact, it was subsequently published in 2009 by Future Medicine as a standalone supplement ('The Little Purple Book') [4-6] to the flagship journal Regenerative Medicine. Scientific breakthroughs, innovation and the overall pace of progress for both regenerative medicine and cell therapy has vastly increased over the last 4 years, and as a result, a great many new terms have come into existence. Therefore, Future Medicine is very proud to publish the second edition of what has become a highly popular and much used glossary as a supplement to this current issue [7].

Since the first edition [4], one significant development to note is the 'spinning out' from regenerative medicine of cell therapy as a dominant platform technology in its own right. Cell therapy is now demonstrating medical capability across a very broad spectrum of clinical indications, from regenerative medicine to cell cancer vaccines. The title of this second edition of 'The Little Purple Book' [7] thus contains both terms, as well as their distinctly different definitions within the main text.

The same team of collaborators that delivered the original version - BSI, London Regenerative Medicine Network (LRMN) and Future Medicine - have, once again, greatly enjoyed working together to produce an updated, revised and reformatted new edition. As before, Alex Kay has expertly managed and coordinated the project from start to finish. We are all extremely grateful to the UK Department of Business, Innovation and Skill (BIS) for providing the necessary funding. We would also like to thank the Rt Hon. David Willetts, MP, the UK government Minister of State for Universities and Science, for his robust support, including providing the Preface as an introduction to the new glossary.

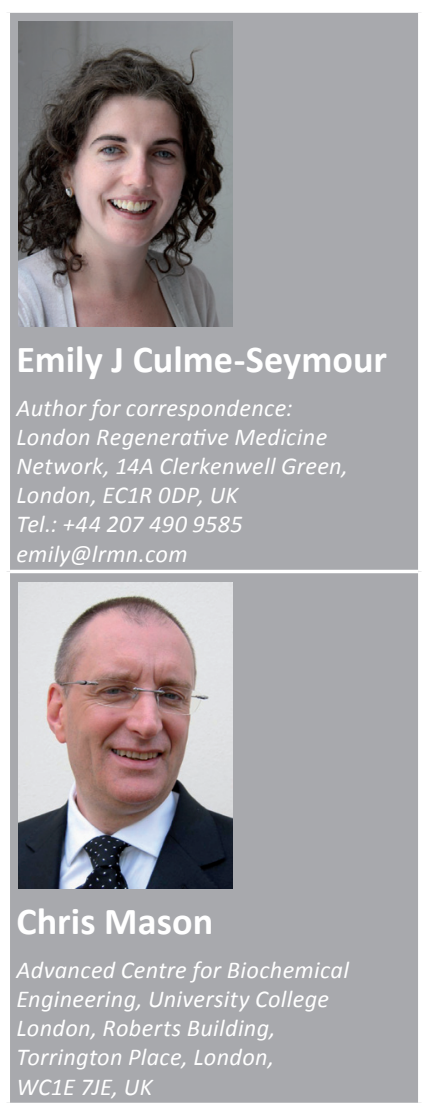

Future :
Medicine $\%$ part of 
To bring a historical perspective to the timeline for the glossary, the original edition coincided with the Olympic Games in Beijing in 2008. This year London is the host city, and when the next edition of the glossary is produced, sporting eyes will all be on Rio de Janeiro. Currently, cell therapy and regenerative medicine are moving from their respective discovery phases into clinical translation. By the time the Olympic Games opens in Brazil, translation will be transitioning to commercialization for both cell therapies and regenerative medicine. Once again, 'The Little Purple Book' will be transformed to meet the challenges of 2016 and, as usual, will be going for gold!
Financial \& competing interests disclosure

C Mason is the Principle Investigator and EJ CulmeSeymour is an investigator on the British Regen Industry Tool Set (BRITS) project funded by the Technology Strategy Board under their Regenerative Medicine Program: Value Systems and Business Modelling. C Mason and EJ CulmeSeymour were the lead technical expert and technical author, respectively, for the second edition of the Cell Therapy and Regenerative Medicine Glossary. The authors have no other relevant affiliations or financial involvement with any organization or entity with a financial interest in or financial conflict with the subject matter or materials discussed in the manuscript apart from those disclosed.

No writing assistance was utilized in the production of this manuscript.

\section{References}

1 Mason C, Brindley DA, Culme-Seymour EJ, Davie NL. Cell therapy industry: billion dollar global business with unlimited potential. Regen. Med. 6(3), 265-272 (2011).
Mason C, Dunnill P. A brief definition of regenerative medicine. Regen. Med. 3(1), 1-5 (2008).
3 Christensen CM, Grossman JH, Hwang J. The Innovator's Prescription: A Disruptive Solution for Health Care. McGraw-Hill, NY, USA (2009).

4 Regenerative medicine glossary. Regen. Med. 4 (4 Suppl.), S1-S88 (2009).

5 Sheridan B, Harris N. New glossary of terms used in regenerative medicine: standardization continues to emerge as regenerative medicine matures. Regen. Med. 4(4), 621-622 (2009).

6 Mason C, Manzotti E. 'The Little Purple Book': BSI glossary of regenerative medicine. Regen. Med. 4(4), 483-484 (2009).

7 Cell therapy and regenerative medicine glossary. Regen. Med. 7(3 Suppl.), S1-S124 (2012). 